\title{
Review and Evaluation of TDI \\ Diesel Generator Owners' \\ Group Program Plan
}

June 1984

Prepared for

the U.S. Nuclear Regulatory Commission

under Contract DE-AC06-76RLO 1830

NRC FIN B2952

Pacific Northwest Laboratory

Operated for the U.S. Department of Energy

by Battelle Memorial Institute 


\title{
DISCLAIMER
}

This report was prepared as an account of work sponsored by an agency of the United States Government. Neither the United States Government nor any agency thereof, nor any of their employees, makes any warranty, express or implied, or assumes any legal liability or responsibility for the accuracy, completeness, or usefulness of any information, apparatus, product, or process disclosed, or represents that its use would not infringe privately owned rights. Reference herein to any specific commercial product, process, or service by trade name, trademark, manufacturer, or otherwise, does not necessarily constitute or imply its endorsement, recommendation, or favoring by the United States Government or any agency thereof. The views and opinions of authors expressed herein do not necessarily state or reflect those of the United States Government or any agency thereof.

\author{
PACIFIC NORTHWEST LABORATORY \\ operated by \\ BATTELLE \\ for the \\ UNITED STATES DEPARTMENT OF ENERGY \\ under Contract DE-AC06-76RLO 1830
}


REVIEW AND EVALUATION

OF TDI DIESEL GENERATOR

OWNERS' GROUP PROGRAM PLAN

June 1984

Prepared for

Division of Licensing

Office of Nuclear Reactor Regulation

U.S. Nuclear Regulatory Commission

under Contract DE-ACU6-76RL0 1830

NRC FIN B2952

Project Title: Assessment of Diesel Engine Reliability/0perability

NRC Lead Engineer: C. H. Berlinger

Pacific Northwest Laboratory

Richland, Washington 99352 
PACIFIC NORTHWEST LABORATORY PROJECT APPROVALS

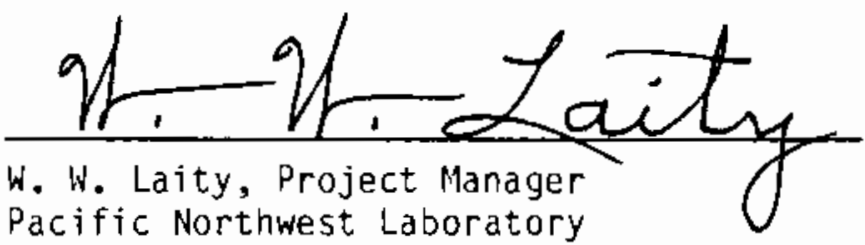

Date July 3, 1984

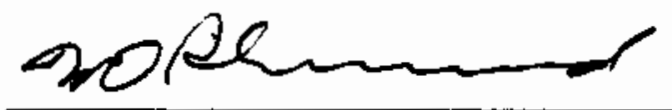

Date $7-3-84$

W. D. Richmond, Chairman

Senior Review Panel

Pacific Northwest Laboratory

if 
CONCURRENCES

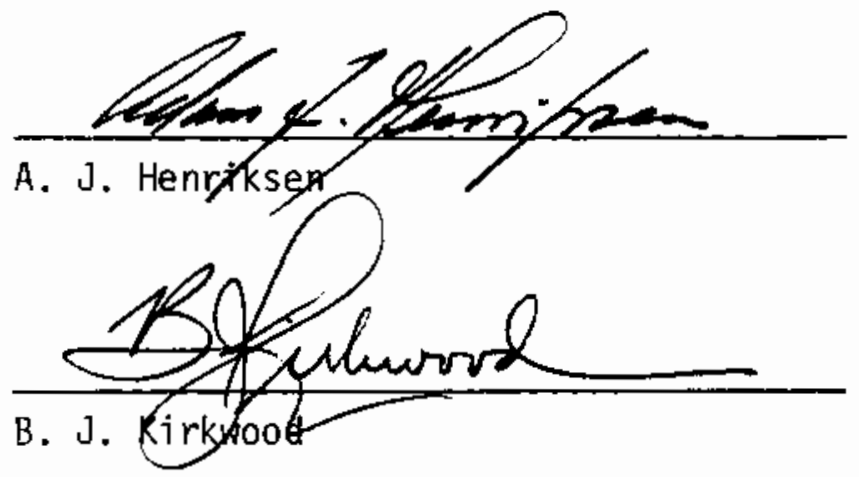

Date $\quad 6 / 29 / 68$

A. J. Henriksen
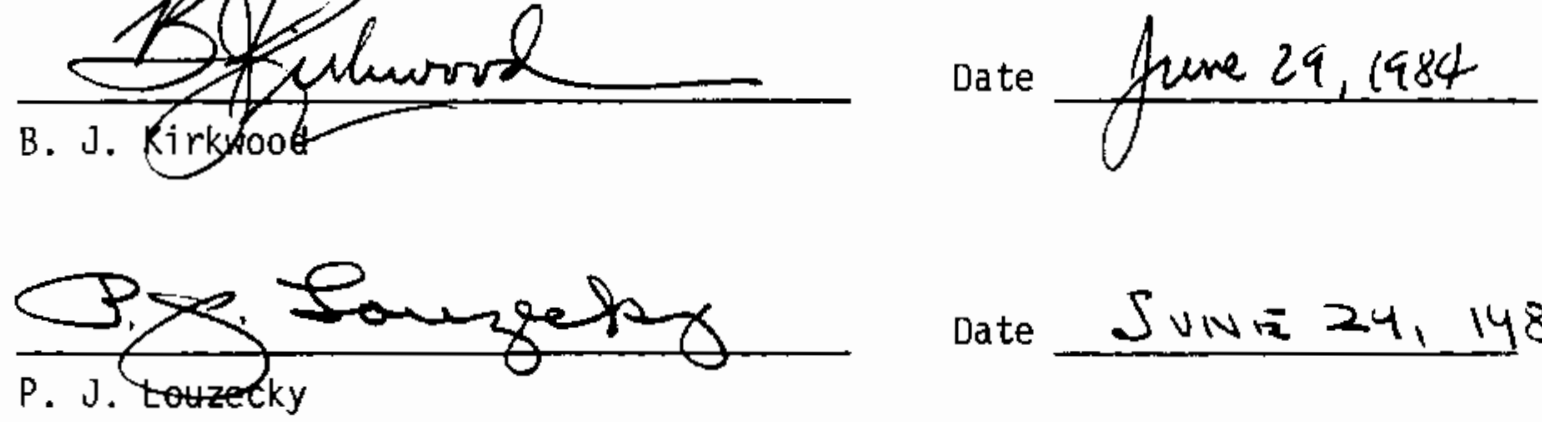

Date Suing 24, 1484

uther hosta

A. Sarsen

Date Jame 29,1984

The above consultants concurred on an unedited version of this report.

$i i j$ 


\section{ABSTRACT}

This report documents a review, performed by the Pacific Northwest Laboratory (PNL), of the Transamerica Delaval, Inc. (TDI) Diesel Generator Owners' Group Program Plan. This report was prepared as part of the technical support PNL is providing to the U.S. Nuclear Regulatory Commission (NRC), Division of Licensing, on matters pertaining to the reliability of TDI diesel generators as emergency power sources for safety-related nuclear systems. Dr. Carl H. Berlinger is NRC's TDI Project Group Leader.

The report presents the comments and conclusions reached by PNL, with the advice and counsel of five diesel engine consultants, on the principal elements of the Owners' Group Plan: Generic Problem Resolution, Design Review/Quality Revalidation, and Engine Testing and Inspection. Also included are PNL's comments on the related issues of Surveillance and Maintenance, and Administrative Controls. The conclusions drawn from PNL's evaluation of these issues form the basis for two additional topics addressed in the report: Critical Elements Required to Establish Diesel Engine Operability and Reliability, and Considerations for Interim Licensing. 


\section{CONTENTS}

ABSTRACT $\ldots \ldots \ldots \ldots \ldots \ldots \ldots \ldots \ldots \ldots \ldots \ldots \ldots \ldots \ldots \ldots \ldots \ldots \ldots \ldots \ldots \ldots \ldots \ldots \ldots \ldots \ldots$

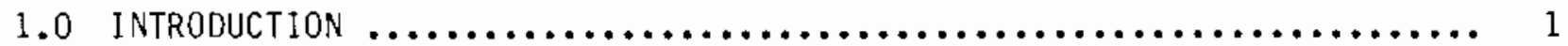

2.0 REVIEW OF OWNERS' GROUP PROGRAM PLAN $\ldots \ldots \ldots \ldots \ldots \ldots \ldots \ldots \ldots \ldots \ldots \ldots$

2.1 KNOWN PROBLEM RESOLUTION $\ldots \ldots \ldots \ldots \ldots \ldots \ldots \ldots \ldots \ldots \ldots \ldots \ldots \ldots \ldots$

2.1 .1 Owners' Group Plan $\ldots \ldots \ldots \ldots \ldots \ldots \ldots \ldots \ldots \ldots \ldots \ldots \ldots \ldots$

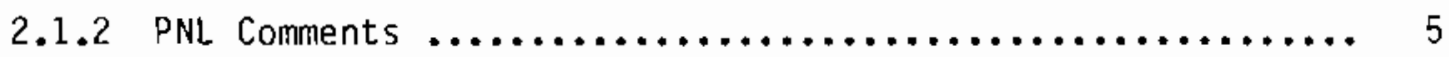

2.2 DESIGN REVIEW/QUALITY REVALIDATION $\ldots \ldots \ldots \ldots \ldots \ldots \ldots \ldots \ldots \ldots \ldots$

2.2 .1 Owners' Group Plan $\ldots \ldots \ldots \ldots \ldots \ldots \ldots \ldots \ldots \ldots \ldots \ldots \ldots . \ldots$

2.2 .2 PNL Comments $\ldots \ldots \ldots \ldots \ldots \ldots \ldots \ldots \ldots \ldots \ldots \ldots \ldots \ldots \ldots \ldots$

2.3 ENGINE TESTING AND INSPECTION $\ldots \ldots \ldots \ldots \ldots \ldots \ldots \ldots \ldots \ldots \ldots \ldots \ldots$

2.3 .1 Owners' Group Plan $\ldots \ldots \ldots \ldots \ldots \ldots \ldots \ldots \ldots \ldots \ldots \ldots \ldots \ldots$. 11

2.3 .2 PNL Comments $\ldots \ldots \ldots \ldots \ldots \ldots \ldots \ldots \ldots \ldots \ldots \ldots \ldots \ldots \ldots \ldots$

2.4 Surveillance And MAInTEnANCE $\ldots \ldots \ldots \ldots \ldots \ldots \ldots \ldots \ldots \ldots \ldots \ldots \ldots \ldots \ldots$

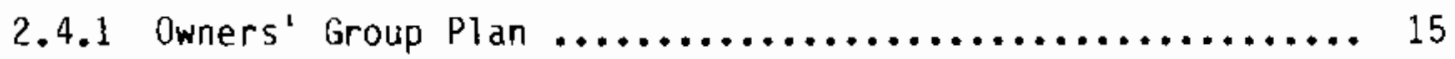

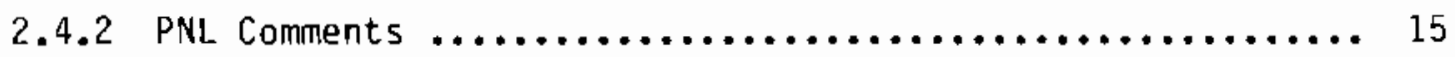

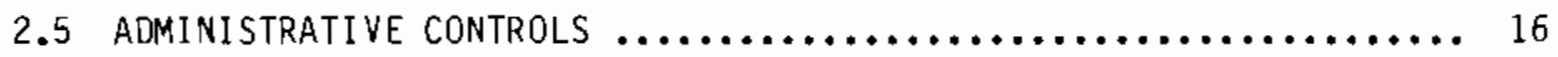

2.5 .1 Owners' Group Plan $\ldots \ldots \ldots \ldots \ldots \ldots \ldots \ldots \ldots \ldots \ldots \ldots \ldots \ldots$

2.5 .2 PNL Comments $\ldots \ldots \ldots \ldots \ldots \ldots \ldots \ldots \ldots \ldots \ldots \ldots \ldots \ldots \ldots \ldots$

3.0 CRITICAL ELEMENTS REQUIRED TO ESTABLISH DIESEL ENGINE OPERABILITY AND RELIABILITY $\ldots \ldots \ldots \ldots \ldots \ldots \ldots \ldots \ldots \ldots \ldots \ldots \ldots \ldots \ldots \ldots \ldots$

4.0 CONSIDERATIONS FOR INTERIM LICENSING $\ldots \ldots \ldots \ldots \ldots \ldots \ldots \ldots \ldots \ldots \ldots \ldots \ldots$ 
REVIEW AND EVALUATION OF

TDI DIESEL GENERATOR OWNERS' GROUP PROGRAM PLAN

\subsection{INTROUUCTION}

Eleven nuclear utilities that own diesel generators manufactured by Transamerica Delaval, Inc. (TDI) have established an Owners' Group to address questions raised by a major failure in one TDI diesel (at the Shoreham Nuclear Power Station in August 1983), and other problems in TDI diesels, On March 2, 1984, the Owners' Group submitted a plan to the U.S. Nuclear Regulatory Commission (NRC) for "...a comprehensive program which, through a combination of design reviews, quality revalidations, engine tests and component inspections, will provide an in-depth assessment of the adequacy of the respective utilities' TDI engines to perform their intended safety related functions."

At the request of NRC, Pacific Northwest Laboratory (PNL) undertook a project to provide support to NRC staff in addressing questions of TDI diesel generator reliability, operability, and quality assurance. A primary task of the project is PNL's assessment of the TDI Diesel Generator Owners' Group Program Plan.

Summarized in this report are the comments and conclusions reached by PNL, with the advice and counsel of five diesel engine consultants, after our review and evaluation of the Owners' Group Program Plan. We focused our attention on three aspects of the Plan:

- adequacy of the overall approach for identifying and correcting significant problems with TDI diesels, and for verifying the suitability of these engines as power sources for safety-related nuclear systems

- thoroughness of the planned effort for addressing all aspects of TDI diesel operability and reliability that should be covered

- critical elements that should be considered in interim licensing decisions (i.e., licensing prior to completion of the implementation of the Plan). 
This report reflects the advice of four PNL consultants in diesel engine technology who met at PNL on May 2 and 3, 1984, to discuss their initial review and evaluation of the Owners' Group Plan, and on June 28, 1984, to discuss this report in its final form. Comments received from NRC on a draft version of this report were considered in the preparation of the final version. The consultants who participated in these meetings are as follows:

- Mr. A. J. Henriksen, private consultant

- Mr. B. J. Kirkwood, Covenant Engineering

- Mr. P. J. Louzecky, Engineered Applications Corporation

- Dr. A. Sarsten, Norwegian institute of Technology.

Mr. J. A. Webber of Ricardo Consulting Engineers PLC, West Sussex, England, participated in a meeting at PNL on April 2 and 3, 1984, to develop an approach for evaluating the Owners' Group Program Plan. Key issues discussed in that meeting that pertain to PNL's review of the Plan are also incorporated in this report.

Members of the PNL project team who participated in the above-mentioned meetings are:

- W. W. Laity, Project Manayer

- J. M. Alzheimer

- M. Clement

- S. D. Dahlgren

- D. A. Dingee

- R. E. Dodge

- J. F. Nesbitt

- J. C. Spanner

- F. R. Zaloudek.

S. H. Bush, a retired PNL staff member currently serving as a consultant to the project, also participated in these meetings on a part-time basis. 


\section{U REVIEH OF OWNERS' GROUP PROGRAM PLAN}

The Owners' Group Program Plan encompasses three major elements for establishing the adequacy of TDI diesel engines to serve as emergency power sources for safety-related nuclear systems. These elements, and a summary of the action planned by the Owners' Group on each, are as follows:

- Generic Problem Resolution - Evaluate and resolve significant problems with potentially generic applicability that have been identified in 16 components, and prepare reports on these components that will provide a basis for near-term licensing decisions involving TOI diesels.

- Design Review/Quality Revalidation - Through reviews of the Parts Manuals supplied by TDI, identify the critical components of TDI engines in addition to the 16 referred to above and assure that these components are properly designed and fabricated. A comprehensive Component Data Base of parts will be generated for each power plant, and the parts classified into one of three categories, depending on their importance for engine operation.

- Engine Testing and Inspection - Establish special or expanded engine tests and component inspections as appropriate to verify the adequacy of the engines and components to perform their intended functions.

These three elements are illustrated schematically in Figure 1 as part of an overall approach for establishing diesel engine operability and reliability. Included in Figure 1 are factors that warrant attention, according to PNL's consultants, in the action planned to correct deficiencies, verify the adequacy of the corrective action, and apply the lessons learned to all engines of the same class. Many of these factors are included explicitly or implicitly in the Owners' Group Program Plan. These factors and related issues identified in PNL's review of the $\mathrm{Plan}$ are discussed under the five subheadings that follow:

- Known Problem Resolution

- Design Review/Quality Revalidation

- Engine Testing and Inspection

- Surveiliance and Maintenance

- Administrative Controls. 


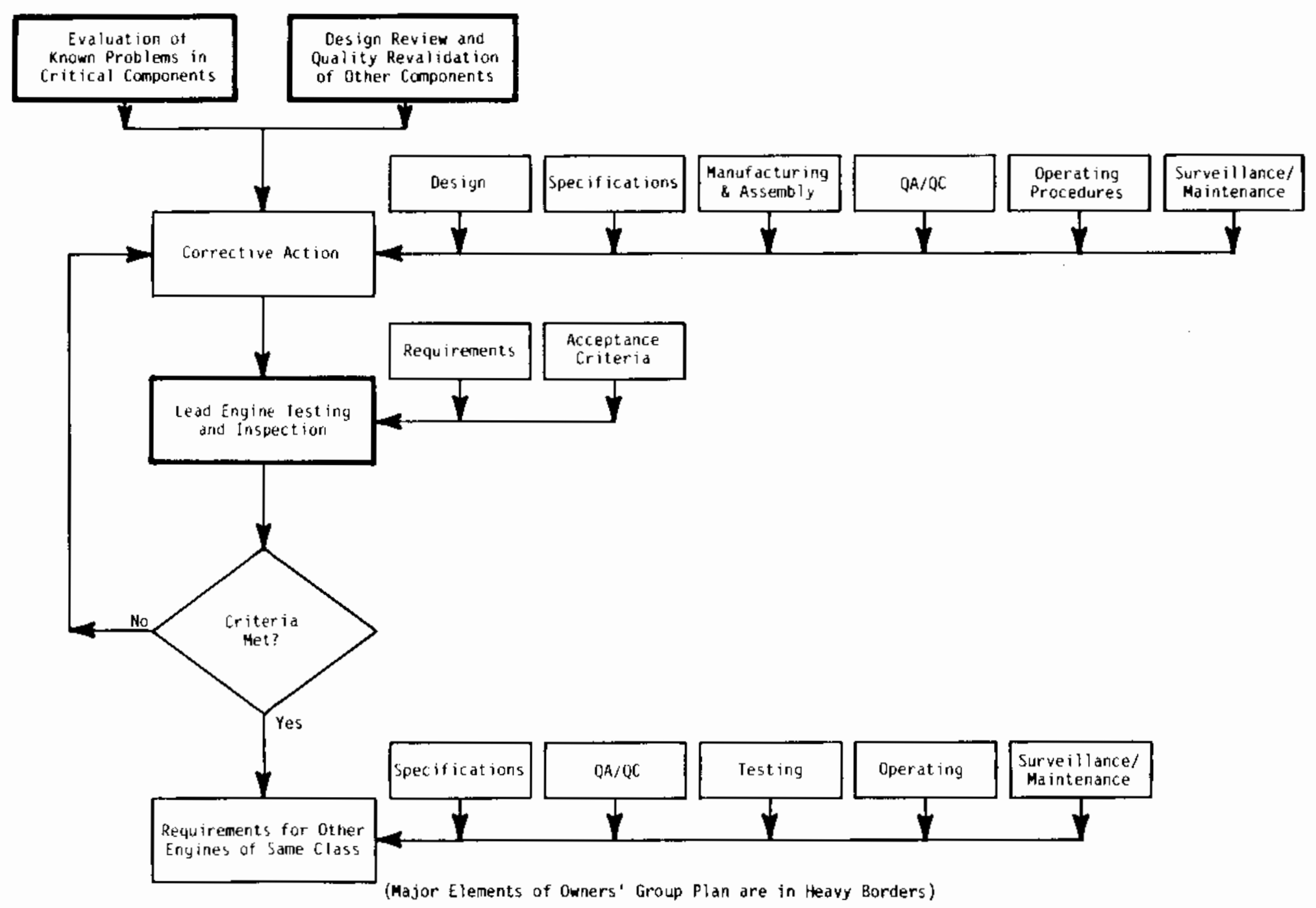

FIGURE 1. Approach for Establishing Diesel Engine Reliability/Operability 


\subsection{KNOWN PROBLEM RESOLUTION}

\section{1 .1 Owners' Group Plan}

On the basis of a review of accumulated data on TDI diesel generator operating experiences from industry sources (nuclear, marine, stationary), the Owners' Group has identified 16 components with problems that have potentially generic applicability. These components are listed in Table 1, together with PNL's estimate of the anticipated complexity in resolving the known problems in each.

Included in the Owners' Group Plan is a task description for the design review of each of these components, and a summary of the analysis, testing, and inspection planned for each component in the lead engine(a) of a given model(b) and for other engines of the same model. As stated in the Plan, the Owners' Group recomnends that these problems be resolved before placing the engines in service to support full-power operation of a nuclear plant. However, exceptions are considered permissible by the Owners' Group to the extent that interim operation prior to problem resolution may be justified by any owner.

\section{1 .2 PNL Comments}

Pacific Northwest Laboratory concurs with the Owners' Group that resolution of known problems is a major element of the effort necessary to establish the operability and reliability of TDI engines. This element takes on added importance if, as stated in the Owners' Group Plan, the reports on these problems "...will provide the bases for the licensing of the early TDI plants...".

(a) Under the lead engine concept, design changes would be verified through testing in one engine (the "lead" engine) and the verification would be considered applicable to other engines equipped with the same components and operated under the same conditions (the "following" engines). Recognizing that corrective actions are not yet identified for all components with known problems, and that components of different design may be used in engines of the same model (e.g., AN piston skirts at Catawba and $A E$ skirts at Grand Gulf), there may be more than one "lead" engine of the same model.

(b) The word "model" as used in this report refers to the manufacturer's designation for a particular engine design (e.g., the DSRV-16 engine). 
TABLE 1. Components with Known Problems Identified by Owners' Group

Components with

known Problems

1. Piston skirts

2. Connecting rod bearing shells

3. Rocker arm cap screws

4. Air-start valve cap screws

5. Cylinder head studs

6. Push rods

7. HP fuel oil tubing

8. Crankshaft

9. Turbocharger

10. Connecting rods

11. Engine base and bearing caps

12. Cyilinder heads

13. Cylinder liner

14. Cylinder block

15. Engine-mounted electrical cable

16. Jacket water pumps $\frac{\text { Complexity of Resolution (Anticipated by PNL) }}{\text { Straight- }}$

Forward Intermediate $\quad \frac{\text { Complex }}{x}$

$x$

$x$

$x$

$x$

$x$

$x$

$x$

$x$

$x$

$x$

$x$

$x$

$x$

$x$

$x$ 
Key considerations that warrant particular attention in the Known Problem Resolution program element include:

- identification of root cause(s)

- corrective action - As illustrated in Figure 1, factors that should be considered as appropriate include design, specifications, manufacturing and assembly, quality control/quality assurance, operating procedures, and surveillance and maintenance.

- basis for corrective action - Design changes should be supported by analysis.

- verification of corrective action - Testing may be a key aspect; it is addressed as a separate element of the Owners' Group Program Plan and is discussed in Section 2.3 of this report.

- TDI engines for which corrective action is applicable - Considerations include engine classification (e.g., R-48), engines in which the component in question is used, rated engine load, and the engineflywheel-generator assembly for components that transmit shaft power. For example, action to correct a crankshaft problem will apply only to engines of the same type that are rated for the same load, and that are equipped with generators and flywheels with the same torsional vibration characteristics.

- implementation of corrective action for all engines to which it is applicable, and verification of implementation - Formal criteria should be established by the Owners' Group for this process.

- life-cycle performance - Action to assure continued satisfactory performance of the lead engine and other engines of the same class should be identified. A key aspect of this action should be a longterm surveillance and maintenance program appropriate for diesel engines in nuclear service.

The PNL team and consultants reviewed those sections of the Owners' Group Plan pertaining to this program element, as well as reports submitted by the 
Uwners' Group through May on known problems. We noted the following items, which, in our opinion, warrant additional attention:

- content of reports on known problems - Reports received from the Uwners' Group generally lack information on one or more of the fundamental aspects (e.g., those listed above) of the identification and resolution of problems and/or malfunctions. PNL's views on this issue are documented in letters to NRC dated April 18 and June 4, 1984, and were discussed with the Owners' Group during a meeting on April 26. Matters that require clarification or elaboration as identified in letters documenting PNL's reviews of the reports should be addressed by the Owners' Group in written responses, or the reports should be reissued with these responses.

- provision for addressing new problems - According to Section III.A, paragraph 4, of the Owners" Group Plan, "...the results of ongoing Owners Group design reviews or owners testing/inspection results as part of the DR/QR efforts may result in revision to this listing" (of known problems). The Owners' Group should make formal provisions for addressing additional, potentially generic problems with TDI engines that may be identified through testing, inspection, expert opinion, and/or operating experience in nuclear or non-nuclear (e.g., stationary) applications. An example of a potential problem that has been identified by PNL consultants is the apparent cracking in wrist pin bushings (both new and used) of TDI engines at the Shoreham Nuclear Power Station.

- critical components - Certain components are particularly important for the reliability and operability of a diesel engine. Potential consequences of failure of these components include immediate shutdown of the engine, possibly severe engine damage, extensive outage for repairs, and, depending on the circumstances, a potentially severe hazard to operating personnel in the vicinity of the engine. Accordingly, any problems identified with these components warrant 
particularly careful attention relative to the "key considerations" summarized earlier in this section. Components in this category include:

--crankshaft

- -connecting rods

--connecting rod bearings

-wrist pin bushings(a)

--cylinder heads

--turbocharger

- -pistons

--gears. (a)

\subsection{UESIGN REVIEW/QUALITY REVALIDATION}

\section{2 .1 Owners' Group Plan}

The second element of the Owners'Group Plan, Design Review/Quality Revalidation, entails a review of components other than those already identified as having known problems (Section 2.1, above). Through a process that considers the function of each component, its role in the overall operation of the engine, known performance data, and the engineering judgment of the Uwners' Group Component Selection Committee, components are selected for design review and/or quality revalidation to assure that they are adequately designed and fabricated.

According to guidelines established by the Owners' Group, a component is normally selected for $D R / Q R$ if its failure would result in engine shutdown ("Type A" component). The Component Selection Committee determines whether or not $D R / Q R$ is required for a component if its failure could result in reduced engine capacity ("Type B"). $O R / Q R$ is generally not required for a component if its failure would have little effect on engine performance ("Type $c$ ").

(a) These components were not included on the list of 16 components with known problems identified by the Owners' Group Plan (Appendix 5). However, wrist pin bushings are addressed by the Owners' Group in Design Review of Connecting Rods of Transamerica Delaval Inline DSR-48 Emergency Diesel Generators, FaÁA-84-3-13 (Failure Analysis Associates, April 1984). 


\subsubsection{PNL Comments}

In light of the deficiencies in TDI's quality assurance program identified by the NRC vendor inspection program, PNL concurs that action is necessary to establish the adequacy of the design and quality of key engine components. PNL also concurs that the DR/QR of components other than those for which known problems have been identified need not be a prerequisite for near-term licensing of nuclear power plants with TDI engines, provided that the considerations discussed in Section 4 of this report are addressed.

Any new, potentially significant problems identified in the UR/QR process should be added to the list of known problems discussed in Section 2.1 of this report. The manner in which the Owners' Group plans to do this is not clear.

The UR/QR of components should also include aspects other than design and fabrication. For example, several reports submitted by the Owners' Group on components with known problems have identified assembly and installation procedures as critical to satisfactory operation (e.g., bolt preload). Accordingly, these procedures should also be evaluated as part of the UR/UR process.

To verify the adequacy of the UR/QR performed by the Owners' Group, PNL plans to audit the reports as follows:

- Several (three or four) of PNL's diesel engine consultants will identify 10 to 20 key components. This selection will be independent of the selection made by the Owners' Group, and will include components that our consultants classify as "Type A" and "Type B."

- The consultants will then review the appropriateness of the DR/QR for each of these components, the level of the review performed, and the $\mathrm{DR} / \mathrm{QR}$ action taken on each.

- The results of the audit will form the basis for any additional action that may be necessary. If there is a concensus among PNL's consultants that the components audited have received an adequate DR/QR by the Owners' Group, no further action may be needed. If significant differences exist between the $D R / Q R$ considered 
appropriate by the consultants and the UR/QR performed by the Owners' Group, it will be necessary to establish a course of action for resolving the differences.

\subsection{ENGINE TESTING AND INSPECTION}

\subsubsection{Owners' Group Plan}

The Owners' Group Plan addresses engine testing in two sections. First, the "Testing Program Sumary" of the Plan states that technical staff will use results of component evaluations to establish testing/inspection requirements for "lead" engines, and that these results will dictate the need for tests and inspections of "following" engines. The specific test plans will result from NRC/owner interactions. Second, for the known problem resolution tests, a test/inspection plan is provided for engines at eleven nuclear stations in the series of tables in Section III and Appendix 6 of the Plan.

\section{3 .2 PNL Comments}

The PNL project team and consultants view this program element as the key for tying together corrective actions described in the other major program elements and verifying the adequacy of design changes. However, the tests outlined in the "Testing Program Summary" and in Appendix 6 of the Owners' Group Plan are not sufficient, in our opinion, to demonstrate the adequacy of solutions to known problems.

PNL recommends that the elements summarized below be included in the testing program. The recommended tests are in addition to those already called for in NRC Regulatory Guide 1.108, "Periodic Testing of Diesel Generator Units Used as Unsite Power Systems at Nuclear Power Plants."

Because of the plant-specific nature of engine installations at nuclear power stations, detailed plans for engine tests and inspections should be prepared by individual owners. Key engine data (e.g., temperatures and pressures) should be defined in the test plans, together with requirements for how these data are to be logged. Acceptance criteria for the tests and inspections should also be included in the plans. The plans should reflect recommendations 
of the Owners' Group and the engine manufacturer, and should be submitted to NRC before the tests are conducted.

Engine tests and inspections discussed in this section may be monitored by NRC representatives.

\subsubsection{Pretest Inspections}

Prior to conducting the operational tests of an engine (either "lead" or "following"), the owner shouid verify that the key engine components (e.g., those listed in Table 1) are sound and are consistent with the latest recommendations of the Owners' Group for part model and acceptance criteria. If the engine is in a nuclear power station that is a candidate for a license before the Owners' Group Plan is fully implemented, this verification should be accomplished through engine disassembly sufficient for inspection of all key components. The crankshaft need not be removed for this inspection, uniess evidence is found during the inspection that it should be.

Appropriate nondestructive tests should be performed, defective parts should be replaced, and design improvenents that have been recommended by the Owners' Group and/or the engine manufacturer should be implemented. A possible exception may be made for the engine block and engine base, which may be placed in service if flaws found through nondestructive tests are noncritical, i.e., the flaws are not a pathway for oil or water leakage, are not propagating, and do not otherwise affect the structural integrity of the engine. Any exceptions for these components should be evaluated on a case-by-case basis.

For TDI engines in nuclear power stations that will apply for operating licenses after the Owners' Group Plan is fully implemented, the verification described above may be accomplished through a review of QA/QC records, if the quality control system and the records are adequate. Included in these records should be documentation of key engine components by "design" (e.g., "AE" piston skirts). In the absence of adequate records, this verification should be accomplished through engine disassembly and inspection as discussed above. Even with adequate records it would be desirable to open the engine if it were in storage for more than a few months, and spot-check components for any degradation that may have occurred during storage. 
As part of pretest inspections, crankshaft deflection should be measured under both "hot" and "cold" conditions to verify that crankshaft alignment is within manufacturer's recommendations. The "hot" measurements should be completed within 15 to 20 minutes of engine shutdown. For "following" engines only, the "hot" measurements (but not the "cold" measurements) may be waived prior to the preoperational tests unless otherwise recommended by the manufacturer, but they should be taken at the completion of the 24-hour, preoperational run described in NRC Regulatory Guide 1.108.

\subsubsection{2 "Lead" Engines}

For key engine components subject to fatigue stresses (e.g., the crankshaft), operation at "qualified" load to $10^{7}$ cycles (about 750 hours at $450 \mathrm{rpm}$ ) is recommended to verify design adequacy. "Qualified" load may be taken as 1) the maximum postulated Engineered Safety Feature (ESF) load that the engine may be required to carry, 2) the continuous rating ("nameplate" load) of the diesel generator, or 3) the load specified by the owner in the purchase specifications for the engine. If the engine is qualified at the maximum postulated ESF load and if that load is increased at some later date (due, for example, to a change in the emergency electrical system), the first qualification test may not be applicable. Similarly, a test at a given load may not be applicable to other engines if they are expected to operate at higher loads.

The test to $10^{7}$ cycles does not have to be continuous. For example, it may be necessary to shut down the engine periodically to perform surveillance and maintenance of key engine components (e.g., articulated connecting rods in $V$-engines) in accordance with recommendations of the Owners' Group and/or the engine manufacturer.

This test is not, by itself, sufficient to prove design adequacy. Rather, it is intended to verify the analysis on which the design of a component is based, by demonstrating that the component will meet load and service requirements without evidence of distress under conditions that could induce highcycle fatigue. On the basis of common industry practice, a test to at least 
$10^{7}$ cycles is necessary for this verification. Together with the analysis, satisfactory completion of this test will provide reasonable assurance of design adequacy.

Following this test, crankshaft deflection should be remeasured under both "hot" and "cold" conditions to determine changes, if any, from pretest measurements. The deflection data are needed to establish the stability of crankshaft alignment.

The engine should then be disassembled to the extent necessary for inspection of all key engine components, and the nondestructive tests discussed in Section 2.3.2.1 should be repeated. Results of all inspections should be recorded, and compared with corresponding information from pretest inspections. All parts found to be defective should be replaced, with the possibie exceptions noted in Section 2.3.2.1. If a key component fails the test, the root cause should be identified, corrective action taken, and the component retested to the full $10^{7}$ cycles. Retesting should be performed in either the "lead" engine, or in another engine where the component will be subject to equal or greater loads.

Following assembly, "hot" and "cold" crankshaft deflection should be remeasured to verify proper alignment. Preoperational testing should also be performed to confirm that the engine is operable. This testing should include the manufacturer's preoperational test recommendations and the following elements, if they are not already included in the manufacturer's recommendations:

- ten modified starts to at least $40 \%$ of "qualified" load

- two fast starts to "qualified" load

- one 24-hour run at "qualified" load.

A modified start is defined as a start including a prelube period as recommended by the manufacturer and a 3 - to 5-minute loading to the specified load level, with operation at the level for a minimum of 1 hour. A fast start is one conducted from the control room on simulation of an Engineered Safety Feature (ESF) signal with the engine on ready standby status. The engine should be loaded to "qualified" load and run for 4 hours at that load on each fast-start test. The 24 -hour run is recommended to detect abnormal 
temperatures, pressures, and/or temperature excursions that might indicate abnormal engine behavior. Either a modified or a fast start may be utilized.

\subsubsection{3 "Following" Engines}

To be considered a "following" engine, the maximum operating load of that engine should be no greater than the "qualified" load at which the "lead" engine has been tested, and the engine shouid meet the definition summarized in the footnote on page 5 of this report. "Following" engines should receive preoperational testing recommended by the manufacturer and/or NRC Regulatory Guides. These tests are considered sufficient to verify proper engine assembly and operation.

At the completion of these preoperational tests, crankshaft deflection should be measured under both "hot" and "cold" conditions for comparison with pretest measurements (described in Section 2.3.2.1). If engine operating conditions (e.g., temperatures and pressures) remain within normal limits and show no abnormal excursions, additional post-test engine disassembly and inspection need not be performed except as recommended by the manufacturer and/or the Owners' Group (e.g., periodic inspections of bolted joints on articulated connecting rods), or as may be required by NRC on the basis of information that may come to light during implementation of the Owners' Group Plan. However, the engine should be barred-over 4 to 8 hours after shutdown to detect any leakage of cooling water through the cylinder heads into the cylinders, and this check should be repeated at intervals established in the engine surveillance and maintenance procedures.

\subsection{SURVEILLANCE AND MAINTENANCE}

\subsubsection{Owners' Group Plan}

The Owners' Group Plan does not specifically address surveillance and maintenance activities.

\subsubsection{PNL Comments}

PNL views a comprehensive surveillance and maintenance program as a key aspect of the overall effort for establishing TDI diesel engine operability and reliability. Such a program contributes to continued satisfactory engine per- 
formance and facilitates the timely identification of potential engine problems. Recommendations for a definitive surveillance and maintenance program should be developed by the Owners' Group in consultation with the engine manufacturer, and detailed plans based on these recommendations should be developed for each engine installation by individual owners. The plans should be provided to NRC.

\subsection{ADMINISTRATIVE CONTROLS}

2.5.1 Dwners' Group Plan

The Owners' Group Plan provides a charter and organization for carrying out the program. The Plan also provides bar-chart scheduling plans. Specific provisions are made for approvals in conjunction with the component selection for the $O R / Q R$ elements of the Plan.

\section{5 .2 PNL Comments}

Certain aspects of administrative controls established by the Owners" Group are not evident from the Program Plan. Those pertaining to resolution of known problems, identification of new problems, and implementation of corrective action are of particular importance for establishing the reliability of TDI engines. Formal procedures should be established for:

- identifying new, potentially significant problems and adding them to the list of those al ready being addressed by the Owners' Group

- disseminating corrective actions to all members of the Owners' Group

- reviewing reports on known problems for the content discussed in Section 2.1.2, above - The Owners' broup Technical Program Virector should certify by his signature that the review addresses all pertinent issues and is complete within itself. 


\subsection{CRITICAL ELEMENTS REQUIRED TO ESTABLISH TDI ENGINE OPERABILITY AND RELIABILITY}

The program logic of Figure 1 forms a basis for identifying the critical elements needed to establish TDI engine operability and reliability for nuclear service (i.e., program elements that should be accomplished prior to licensing action). The evaluation of the Owners' Group Plan in Section 2.0 reflects these elements, which are:

- For key engine components (e.g., those listed on page 9) necessary actions include the following: 1) the Owners' Group should assure NRC that all significant problems (e.g., those that can lead to immediate or eariy engine shutdown or capacity limitation) with TDI engines have been identified; 2) the causes of each identified problem should be determined to the satisfaction of NRC (viz. design and specifications, materials and fabrication, $Q A / Q C$, installation, maintenance, or operations); and 3) a program for resolving these problems should be established and submitted to NRC. Standards of performance in these areas have been suggested to NRC in a letter from PNL dated April 18, 1984.

- The corrective action should be implemented and the individual owners should confirm that the intended action has been taken (e.g., design changes, materials changes, and changes to operation and maintenance procedures). This would include, as appropriate, testing and inspection described below.

- Lead-engine testing and inspection of any new or changed component should be completed. This should include the testing elements identified in Section 2.3.2. A plan for these tests should be submitted to NRC by the Owners' Group in advance of the tests. These tests and inspections may be monitored by NRC representatives.

- Each "lead" and "following" engine should undergo preoperational testing as described in Section 2.3.2. 
- A plan to assure continued satisfactory performance of engines in service should be estab1ished by the Owners' Group and provided to NRC. The principal element of the plan is the surveillance and maintenance program.

- A procedure should be established to communicate future industry problems and disseminate corrective actions to all nuclear industry owners of TDI engines. 


\subsection{CONSIDERATIONS FUR INTERIM LICENSING}

Certain plants may be candidates for near-term operating licenses prior to completion of the implementation of the Uwners' Group Plan. Because of the plant-specific aspects of these licenses, they will need to be treated on a case-by-case basis. Summarized in this section are factors that PNL recommends for consideration in this process.

The lead-engine tests and inspections discussed in Section 2.3.2 of this report should be a prerequisite for a license to operate a reactor at power leveis that would require a diesel generator to carry an emergency load corresponding to engine Brake Mean Effective Pressure (BMEP) greater than 185 psig. If the BMEP would not exceed 185 psig under emergency conditions, and if the engine is equipped with $A E$ piston skirts, the tests and inspections could be performed in parallel with operation of the reactor under an interim iicense. This BMEP limit as a condition for an interim license is based on the following considerations:

- Most of the operating experience with AE piston skirts of which PNL is aware has been at Kodiak, Alaska, where a TDI engine reportedly has accumulated in excess of 6,000 hours without piston-skirt failure.(a) A substantial portion of this operation reportedly has been at a power level that corresponds to a maximum cylinder pressure of about $1,200 \mathrm{psig}$. At the recommended BMEP limit of $185 \mathrm{psig}$, the maximum cylinder pressure is also approximately 1,200 psig. The operating experience at Kodiak establishes a reasonable basis for confidence that AE piston skirts will operate satisfactorily at this load level.

- Pending the evaluation and approval of reports from the Owners' Group that address crankshaft stress levels at higher loads, the load corresponding to 185 BMEP is considered to be reasonably conservative for the crankshaft.

(a) A discussion of this operating experience is documented in the transcript of the TDI Owners' Group meeting held on March 22, 1984 (page $91 \mathrm{ff}$. ). 
- Because of certain open items in the implementation of the Owners" Group Plan, an adequate basis does not yet exist to provide reasonable assurance that TOI diesel engines would operate reliably in nuclear service at power levels higher than those corresponding to a BMEP of 185 psig. Open items include resolution of comments and questions raised by $P N L$ in reviews of reports submitted by the Owners' Group on known problems, verification of corrective actions through engine tests, completion of action items on component task descriptions prepared by the Owners' Group, and design review/quality revalidation of key components. Key engine components of particular concern in this regard include the piston skirts and the crankshaft, because their condition cannot be monitored without significant engine disassembly.

If the criteria are met for power plant operation under an interim license, one of the TDI engines at the power plant could be designated the "lead" engine for the tests and inspections, or the tests and inspections could be performed on a "lead" engine at another power plant. However, the TDI engines at the power plant with the interim license should undergo the preoperational inspections discussed in Section 2.3 .2 of this report, preoperational testing in accordance with manufacturer's recommendations and applicabie NRC Regulatory Guides, and the additional preoperational tests discussed in Section 2.3.2. Furthermore, they should receive enhanced surveillance analogous to the surveillance recommended by PNL for the Grand Gulf Nuclear Power Station in a letter dated April 16, 1984 to NRC. 
DISTRIBUTION

No. of

Copies

UFFSITE

17 Jivision of Licensing

Uffice of Nuclear Reactor Regulation

U.S. Nuclear Kegulatory Commission Washington, UC 20555

ATTN: C. Berlinger (10)

M. Carrington (2)

R. Caruso

D. Corley

U. Eisenhut

F. Miraglia

11. Williams

12 NRC Plant Project Managers

Division of Licensing

U.S. Nuclear Regulatory

Commission

Washington, DC 20555

ATTN: B. Buckley

S. Burwell

D. Hood

v. Houston

K. Jabbour

T. Kenyon

E. Mckenna

M. Miller

S. Miner

C. Stanle

J. Stefano

E. Weinkam

2 NRC Division of Technical

Information and Document Control

Washington, DC 20555

NRC Public Document Room
No. of

Copies

2 DUE Technical Information Center

K. Trickett, NE-14

U.S. Department of Energy

Office of Vuclear Energy

washington, DC zubsb

UNSITE

DOE Richland Uperations Uffice

M. Plahuta

Pacific Northwest Laboratory

$5 \quad$ Consultants

A. Henriksen

B. Kirkwood

P. Louzecky

A. Sarsten

J. Webber

5 Senior Review Panel

R. Albaugh

S. Bush

C. Hill

W. Richrnond

L. Willians

29

Project Team

J. Alzheimer

M. Clement

S. Dahlgren

D. Dingee

R. Dodge

W. Gintner

W. Laity (15)

J. Nesbitt

F. Zaloudek

Technical Information (4)

Publishing Coordination (2) 